\title{
Reversible Effect of Magnetic Fields on Human Lymphocyte Activation Patterns: Different Sensitivity of Naive and Memory Lymphocyte Subsets
}

\author{
Author(s): Sergio Salerno, Carmela La Mendola, Marco Pio La Manna, Antonio Lo Casto, Nadia \\ Caccamo, and Alfredo Salerno
}

Source: Radiation Research, 172(4):444-450.

Published By: Radiation Research Society

DOI: http://dx.doi.org/10.1667/RR1761.1

URL: http://www.bioone.org/doi/full/10.1667/RR1761.1

BioOne (www.bioone.org) is a nonprofit, online aggregation of core research in the biological, ecological, and environmental sciences. BioOne provides a sustainable online platform for over 170 journals and books published by nonprofit societies, associations, museums, institutions, and presses.

Your use of this PDF, the BioOne Web site, and all posted and associated content indicates your acceptance of BioOne's Terms of Use, available at www.bioone.org/page/terms_of_use.

Usage of BioOne content is strictly limited to personal, educational, and non-commercial use. Commercial inquiries or rights and permissions requests should be directed to the individual publisher as copyright holder. 


\title{
Reversible Effect of Magnetic Fields on Human Lymphocyte Activation Patterns: Different Sensitivity of Naive and Memory Lymphocyte Subsets
}

\author{
Sergio Salerno, ${ }^{a}$ Carmela La Mendola, ${ }^{b}$ Marco Pio La Manna, ${ }^{b}$ Antonio Lo Casto, ${ }^{a}$ Nadia Caccamo $^{b}$ and \\ Alfredo Salerno ${ }^{b, 1}$ \\ a Dipartimento di Biotecnologie Mediche e Medicina Legale and ${ }^{b}$ Dipartimento di Biopatologia e Metodologie Biomediche, Università di Palermo, \\ Palermo, Italy
}

\begin{abstract}
Salerno, S., La Mendola, C., La Manna, M. P., Lo Casto, A., Caccamo, N. and Salerno, A. Reversible Effect of Magnetic Fields on Human Lymphocyte Activation Patterns: Different Sensitivity of Naive and Memory Lymphocyte Subsets. Radiat. Res. 172, 444-450 (2009).

The aim of this study was to investigate the influence of $50 \mathrm{~Hz}$ magnetic or static magnetic fields of $0.5 \mathrm{mT}$ on subsets of human $\mathrm{CD4}^{+} \mathrm{T}$ cells in terms of cytokine release/content, cell proliferation and intracellular free calcium concentration. $\mathrm{CD4}^{+} \mathrm{T}$ cells can be divided into different subsets on the basis of surface marker expression, such as $\mathrm{CD} 45$, and $\mathrm{T}$ cells can be divided into naive $\left(\mathrm{CD}^{2} 5 \mathrm{RA}^{+}\right)$and memory $\left(\mathrm{CD}^{4} \mathrm{R} \mathrm{A}^{-}\right)$cells. In this study, the effects of magnetic fields after 24 and $48 \mathrm{~h}$ of cell culture were analyzed. We found that the $\mathrm{CD4} 4^{+} \mathrm{CD} 45 \mathrm{RA}^{-} \mathrm{T}$ subset were more sensitive after $2 \mathrm{~h}$ of exposure. Decreases in the release/content of IFN- $\gamma$, in cell proliferation and in intracellular free calcium concentrations were observed in exposed $\mathrm{CD4}^{+} \mathrm{CD}^{+} 5 \mathrm{RA}^{-} \mathrm{T}$ cells compared to $\mathrm{CD4}^{+} \mathrm{CD} 45 \mathrm{RA}^{+}$ $T$ cells. The results suggest that exposure to the magnetic fields induces a delay in the response to stimulants and that modifications are rapidly reversible, at least after a short exposure. ๑ 2009 by Radiation Research Society
\end{abstract}

\section{INTRODUCTION}

The potential health risk of exposure to extremely low-frequency (ELF) magnetic fields has received considerable attention in recent years, mainly due to the ubiquitous presence of electricity and electrical appliances in the home and workplace, and some findings suggest the occurrence of adverse health effects $(1,2)$.

ELF magnetic fields cover the frequency range of $3 \mathrm{~Hz}-3 \mathrm{kHz}$; the most intensively studied frequency is $50 / 60 \mathrm{~Hz}$. Non-ionizing electromagnetic fields (EMFs) and in particular the ELF magnetic field are able to affect many biological functions (3-6), but current data

${ }^{1}$ Address for correspondence: Dipartimento di Biopatologia e Metodologie Biomediche, Università di Palermo, Corso Tukory 211, 90134 Palermo, Italy; e-mail: asalerno@unipa.it. do not provide a satisfactory explanation for these effects because of the great diversity of specialized biological models and applications studied and the limited information concerning the underlying mechanisms of interaction.

The guidelines for occupational exposure to powerfrequency magnetic fields at $50 \mathrm{~Hz}$ are (1) $0.5 \mathrm{mT}$ for the International Committee on Non-ionizing Radiation Protection (ICNIRP) (7) and for the International Radiation Protection Association (IRPA) (8), (2) 0.1 $\mathrm{mT}$ for exposures to the general public, (3) $1 \mathrm{mT}$ for the American Conference of Governmental Industrial Hygienists (ACGI), and (4) $0.5 \mathrm{mT}$ for the World Health Organization's International Agency for Research on Cancer (1). While many studies have demonstrated that ELF sinusoidal $50 / 60 \mathrm{~Hz}$ magnetic fields may have harmful effects on human health, other reports have provided inconsistent evidence to support the presence of health hazards due to exposure to EMFs (9-14). Medium-intensity static magnetic fields ranging from 1$1000 \mathrm{mT}$ have been shown to influence a wide variety of biological systems. Knowledge of the effects of static magnetic fields is important for human health. It has been reported that exposure to middle-level static magnetic fields affects the morphology, differentiation and/or proliferation of several cell types (15-18).

In our previous paper (11), we showed that magnetic fields can influence some cellular functions, but these alterations are reversible after $48 \mathrm{~h}$ of in vitro cell culture. In particular, magnetic fields produce a reversible effect on cell proliferation, IFN- $\gamma$ production/release and cytosolic free calcium concentration. In the present study we evaluated the effects of a $0.5 \mathrm{mT}$ $50 \mathrm{~Hz}$ magnetic field and static magnetic field on subsets of human $\mathrm{CD}^{+} \mathrm{T}$ cells with differing expression of CD45RA. Several isoforms of the CD45 protein exist, including CD45RA and CD45RO. These molecules are involved in various aspects of lymphocyte activation. CD45RA is expressed on naïve T cells, while $T$ cells that have previously encountered this antigen express CD45RO. The number of $\mathrm{CD}^{2} \mathrm{RO}^{+}$cells increases 
with age, and approximately $45 \%$ of the T-cell population expresses this isoform. In the present study we investigated the effects of $50 \mathrm{~Hz}$ magnetic fields and static magnetic fields on the different subsets of $\mathrm{CD}^{+} \mathrm{T}$ cells in terms of the release/content of IFN- $\gamma$, cell proliferation and modification of intracellular cytosolic free calcium content to identify the subsets the were more sensitive to the effects of magnetic fields.

\section{MATERIALS AND METHODS}

\section{Subjects}

Blood samples were obtained from eight healthy volunteers (four females and four males) with a mean age of $30 \pm 3$ years (age range $27-33$ years); informed consent was obtained from all participants. The analyses were done blindly by two independent research groups.

The internal committee of the Department of Biopathology, Palermo, oversaw the procedures for the collection of the blood samples from $10 \mathrm{ml}$ of heparinized peripheral blood that were used for the generation of anonymized CD4 T-cell lines.

$\mathrm{CD}^{+}{ }^{+} \mathrm{T}$-cell lines were generated from peripheral blood mononuclear cells (PBMC) isolated from heparinized blood by centrifugation on Ficoll-Hypaque (Pharmacia, Uppsala, Sweden). Cells were maintained in RPMI-1640 culture medium (Gibco, Grand Island, NY) supplemented with $10 \%$ heat-inactivated pooled human $\mathrm{AB}^{+}$ serum, $2 \mathrm{~m} M$ L-glutamine, $20 \mathrm{~m} M$ Hepes, $100 \mathrm{U} / \mathrm{ml}$ penicillin, $100 \mu \mathrm{g} / \mathrm{ml}$ streptomycin, $5 \times 10^{-5} M$ 2-mercaptoethanol, and $20 \mathrm{IU} /$ $\mathrm{ml}$ rIL-2, hereafter referred to as IL-2-supplemented culture medium. $\mathrm{CD}^{+} \mathrm{T}$ lymphocytes were sorted by immunomagnetic beads using an anti-CD4 specific monoclonal antibody $(\mathrm{mAb})$ and were then expanded in vitro in IL-2-supplemented culture medium supplemented with purified PHA (Leucoagglutinin, $0.5 \mu \mathrm{g} / \mathrm{ml}$, Sigma, St. Louis, MO) and irradiated (30 Gy from a cesium source) allogeneic feeder cells (PBL and Epstein Barr Virus B cells at a ratio of 10/1). Cells were maintained for 2 weeks without any stimulation before functional analysis. The purity of the $\mathrm{CD} 4^{+} \mathrm{T}$ cells was assessed by two-color flow cytometry. PE-conjugated anti-CD3 mAb was used with FITCconjugated anti-CD4 mAb (both from Becton Dickinson, San Jose, CA). The cells were analyzed using a FACSCalibur flow cytometer (Becton Dickinson, Mountain View, CA). This T-cell procedure induces expansion of virtually all $\mathrm{CD}^{+} \mathrm{T}$ cells and does not introduce any bias in the $\mathrm{T}$-cell repertoire (19).

Cells were split in two groups of samples, one to be exposed to the magnetic fields and the other to serve as a control to be kept under isothermal conditions for the whole time of the experiment. The experiments were carried out in triplicate for each sample and were repeated four times.

\section{Terms and Conditions of Exposure}

Each set of samples included subsets of human CD4 ${ }^{+} \mathrm{T}$ cells. Sham-exposed cells were maintained at $37^{\circ} \mathrm{C}$ while treated cells were exposed and were maintained under the same conditions as the exposed cells after their exposure to the magnetic fields.

The exposures to the $0.5 \mathrm{mT}$ EMF were performed inside a double cylindrical coil (50 $\mathrm{cm}$ and $15 \mathrm{~cm}$ inner diameter). The electric current intensity in the coils ranged between 0 and $8 \mathrm{~A}$ and the measured magnetic-field values were between 0 and $7.5 \mathrm{mT}$. A gaussmeter with an axial Hall effect probe was used to measure the magnetic-field distribution at various points across the solenoid. The overall uncertainty of measurement was $2 \%$. The field inside the exposure area showed about $3 \%$ homogeneity.

The $0.5 \mathrm{mT}$ static magnetic field was generated by double magnet ( $35 \mathrm{~cm}$ and $10 \mathrm{~cm}$ inner diameter). The direct current (d.c.) intensity ranged between 0 and $6 \mathrm{~A}$ and the measured magnetic field values were respectively between 0 and $10 \mathrm{mT}$. The field inside the exposition area showed about $5 \%$ in homogeneity.

The temperature was maintained at $37 \pm 0.5^{\circ} \mathrm{C}$ by a water circulation system connected to a Circulator Haake DC10 temperature regulator (Thermo Fisher Scientific, Karlsruhe, Germany) equipped with connector for external circulation.

All the exposed samples were maintained in the magnetic fields for $2 \mathrm{~h}$; after exposure, the samples were maintained at $37^{\circ} \mathrm{C}$ and then sent to the laboratory for immunological tests.

\section{Immunomagnetic Separation of Exposed and Sham-Exposed Cells}

Sham-exposed and exposed cells were sorted by negative selection with immunomagnetic beads using anti-CD45RA and anti-CD45RO specific monoclonal antibodies (mAbs) according to the Miltenyi Biotec protocol. Briefly, after $2 \mathrm{~h}$ of exposure, sham-exposed and exposed cells were incubated with the antibodies for 15 min at $4^{\circ} \mathrm{C}$. After incubation, the cells were washed with buffer (0.5\% PBS/BSA and $2 \mathrm{~m} M$ EDTA, pH 7.2) and resuspended in $80 \mu \mathrm{l}$ of buffer. Then the cells were incubated with $20 \mu$ of goat anti-mouse IgG beads for $15 \mathrm{~min}$ at $4^{\circ} \mathrm{C}$. After incubation, the cell suspension was placed on top of the column separation (MS Miltenyi), the buffer (1 ml) was added three times, and the negative fraction was collected. The negative fraction, represented by cells without magnetic beads, was washed, resuspended in buffer, and checked by flow cytometry, and used for further experiments.

\section{Determination of IFN- $\gamma$}

Exposed and sham-exposed cells $\left(2 \times 10^{6} / \mathrm{ml}\right)$ were cultured in $24-$ well plates in $1 \mathrm{ml}$ of complete medium in the presence or absence of PHA $(0.5 \mu \mathrm{g} / \mathrm{ml})$ for 24 and $48 \mathrm{~h}$. The PHA was used as polyclonal mitogen that interacts with the T-cell receptor (TCR) or accessory surface structures (indirect TCR crosslinking) used to evaluate the functional activity of $\mathrm{T}$ lymphocytes.

The supernatants were harvested and stored at $-70^{\circ} \mathrm{C}$ until they were tested for cytokines; the cytokine levels were determined using an immunoenzymatic method. The supernatants of cells exposed to $50 \mathrm{~Hz}$ magnetic fields were analyzed with an enzyme-linked immunosorbent assay (ELISA) performed with a reagent set human IFN- $\gamma$ (Euroclone, Devon, UK). The limit detection range was from $12.5 \mathrm{pg} / \mathrm{ml}$ to $400 \mathrm{pg} / \mathrm{ml}$ for IFN- $\gamma$ concentration; instead the supernatants of cells exposed to static magnetic fields were analyzed with reagent set human IFN- $\gamma$ (R\&D Systems, UK). The limit detection range was from $12.5 \mathrm{pg} / \mathrm{ml}$ to $1000 \mathrm{pg} / \mathrm{ml}$ for IFN- $\gamma$ concentration. All tests were performed according to the manufacturer's instructions.

\section{Intracellular FACS Analysis}

Cells were exposed to magnetic fields as described. The cells were stained with PECy.5-labeled anti-CD45RA antibody; then they were washed twice in PBS with 1\% FCS and fixed with PBS with 4\% paraformaldehyde for $30 \mathrm{~min}$ at $4{ }^{\circ} \mathrm{C}$. Fixation was followed by permeabilization with PBS with $1 \%$ FCS, $0.3 \%$ saponin and $0.1 \%$ Na-azide for $15 \mathrm{~min}$ at $4{ }^{\circ} \mathrm{C}$. Alternatively, staining for intracellular antigen was performed by incubating fixed permeabilized cells with FITC-labeled anti-Ki67 antibody and/or with PE-labeled anti-IFN- $\gamma$ antibody (Becton Dickinson). After two more washes in PBS with 1\% FCS, the cells were analyzed by flow cytometry. Viable lymphocytes were gated by forward and side scatter, and analysis was performed on 100,000 acquired events for each sample. Intracellular staining was also used to evaluate the cytosolic free calcium at the single-cell level in both exposed and sham-exposed cell samples after exposure to the $50 \mathrm{~Hz}$ magnetic fields and static magnetic fields. Cells were harvested and fixed with $4 \%$ (w/v) paraformaldehyde in PBS for $10 \mathrm{~min}$ at room temperature. Fixed cells were suspended and washed twice with a 
TABLE 1

Levels of IFN- $\gamma$ Released from CD4 ${ }^{+} \mathrm{CD} \mathrm{RA}^{-} \mathrm{T}$ and $\mathrm{CD4}^{+} \mathrm{CD}^{-} \mathrm{RA}^{+} \mathrm{T}$ Cells Exposed to the $0.5 \mathrm{mT}$ Static Magnetic Field or Sham-Exposed Cells after 24 h of Cell Culture

\begin{tabular}{|c|c|c|c|c|}
\hline & IFN- $\gamma$ & & IFN- $\gamma$ & \\
\hline & Sham-exposed & Exposed & Sham-exposed & Exposed \\
\hline RPMI 1640 & $38 \pm 17$ & $33 \pm 13$ & $34 \pm 15$ & $29 \pm 19$ \\
\hline
\end{tabular}

${ }^{a} P<0.05$

${ }^{b}$ Results are expressed as mean $\mathrm{pg} / \mathrm{ml} \pm \mathrm{SD}$ for eight samples.

permeabilization buffer containing $0.1 \%$ saponin (Sigma-Aldrich, Milano, Italy), $1 \%$ heat-inactivated FCS, and $0.1 \% \mathrm{NaN}_{3}$ in PBS. The cells were then incubated in the presence of a permeabilization buffer with FITC-conjugated Calcein (Sigma-Aldrich, Milano, Italy) for $1 \mathrm{~h}$ at room temperature. After two more washes in PBS with $1 \%$ FCS, the cells were analyzed by flow cytometry. Viable lymphocytes were gated by forward and side scatter, and analysis was performed on 100,000 acquired events for each sample. The calcium concentration was monitored by single-excitation flow cytometry. The fluorescence was recorded at $490 \mathrm{~nm}$ excitation and $520 \mathrm{~nm}$ emission.

\section{Statistics}

The IFN- $\gamma$ concentration was expressed as $\mathrm{pg} / \mathrm{ml}$ and reported as means $\pm \mathrm{SD}$.

The proliferation index was expressed as a percentage of Ki-67positive cells, and statistical evaluation of the data was performed using the stimulation index (median and 25th and 75th percentiles). The FACS analysis of intracellular IFN- $\gamma$ was expressed as the percentage of positive cells, median and 25th and 75th percentiles.

Statistical evaluation of the experimental data was performed with a two-tailed Student's $t$ test on paired samples with $P<0.05$ as the minimum level of significance.

The calcein was expressed as mean fluorescence intensity (MFI) and reported as mean $\pm \mathrm{SD}$.

\section{RESULTS}

Release of IFN- $\gamma$ from $C D 4^{+} C D 45 R A^{-} T$ and $\mathrm{CD}^{+} \mathrm{CD} 45 \mathrm{RA}^{+}$Cells Exposed to $0.5 \mathrm{mT}$ Static Magnetic Fields

We examined the sensitivities of $\mathrm{CD}^{+}{ }^{+} \mathrm{T}$-cell subsets to $0.5 \mathrm{mT}$ in the different $\mathrm{CD} 4^{+} \mathrm{T}$-cell lines used for the experiments.

Table 1 shows the absolute values in $\mathrm{pg} / \mathrm{ml}$ of IFN- $\gamma$ release from $\mathrm{CD}^{+}{ }^{+} \mathrm{CD} 45 \mathrm{RA}^{-}$T-cell subsets and $\mathrm{CD}^{+}{ }^{+} \mathrm{CD} 45 \mathrm{RA}^{+}$T-cell subsets exposed or shamexposed to $0.5 \mathrm{mT}$ static magnetic fields after $24 \mathrm{~h}$ of in vitro culture. A significant difference in the IFN- $\gamma$ values was found only for the exposed CD4 ${ }^{+} \mathrm{T}$ cells stimulated with PHA compared to sham-exposed cells. The difference in the release of IFN- $\gamma$ after $24 \mathrm{~h}$ was significant for the $\mathrm{CD}^{+}{ }^{+} \mathrm{CD} 45 \mathrm{RA}^{-}$T-cell subset exposed to the static magnetic fields compared to the sham-exposed cells, while no significant difference in IFN- $\gamma$ release was found between exposed and nonexposed $\mathrm{CD}^{+}{ }^{+} \mathrm{CD} 45 \mathrm{RA}^{+} \mathrm{T}$ cells. Similar results were found in cells exposed to $50 \mathrm{~Hz}$ magnetic fields, which showed a $25 \%$ inhibition of IFN- $\gamma$ release (data not shown). It is evident that $\mathrm{CD}^{+}{ }^{+} \mathrm{CD} 45 \mathrm{RA}^{-} \mathrm{T}$ cells are more sensitive to static magnetic fields in terms of IFN- $\gamma$ release.

Release of IFN- $\gamma$ from $\mathrm{CD}^{+} \mathrm{CD}^{+} 5 \mathrm{RA}^{-} \mathrm{T}$ and $\mathrm{CD}^{+} \mathrm{CD}^{2} 5 \mathrm{RA}^{+} \mathrm{T}$ Cells Exposed to $0.5 \mathrm{mT} 50 \mathrm{~Hz}$ Magnetic Fields

Figure 1 shows a comparison between the levels of IFN- $\gamma$ released from $\mathrm{CD}^{+}, \mathrm{CD}^{+}{ }^{+} \mathrm{CD} 45 \mathrm{RA}^{-}$and $\mathrm{CD}^{+}{ }^{+} \mathrm{CD}_{45 \mathrm{RA}^{+}} \mathrm{T}$ cells exposed to the $0.5 \mathrm{mT} 50 \mathrm{~Hz}$ magnetic fields and their respective sham-exposed controls after $24 \mathrm{~h}$ of in vitro culture.

The amount of IFN- $\gamma$ in $\mathrm{CD}^{+}$cells cultured in complete medium was produced in equal part by the $\mathrm{CD}^{+}{ }^{+} \mathrm{CD}_{45 \mathrm{RA}^{-}}$and $\mathrm{CD}^{+} \mathrm{CD}^{+} 5 \mathrm{RA}^{+}$subsets in sham-exposed and exposed cells, and exposed $\mathrm{CD}^{+}$ cells showed a small decrease in IFN- $\gamma$ production (14\%) compared to sham-exposed cells.

In cells stimulated with PHA, the amount of IFN- $\gamma$ in $\mathrm{CD}^{+} \mathrm{T}$ cells was produced almost exclusively by the

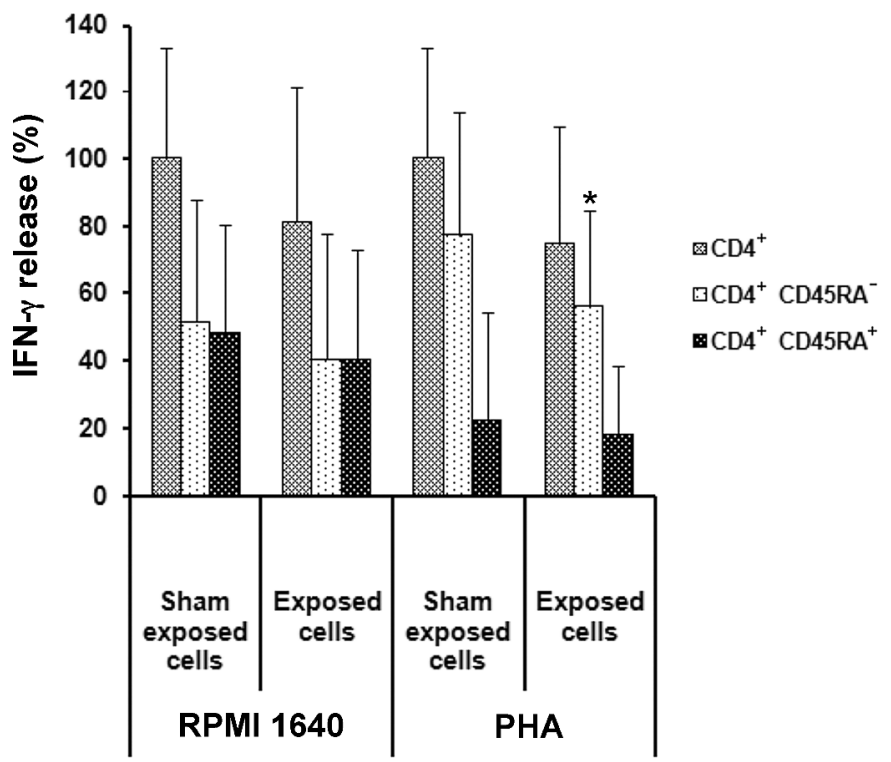

FIG. 1. IFN- $\gamma$ release from $\mathrm{CD}^{+}, \mathrm{CD}^{+}{ }^{+} \mathrm{CD}_{45 \mathrm{RA}^{-}}$and $\mathrm{CD}^{+}$ $\mathrm{CD}^{2} 5 \mathrm{RA}^{+} \mathrm{T}$ cells, sham-exposed or exposed for $2 \mathrm{~h}$ to $0.5 \mathrm{mT} 50 \mathrm{~Hz}$ magnetic fields and stimulated or not with PHA after $24 \mathrm{~h}$ of cell culture in complete medium. Data are expressed as the percentage of release of exposed cells compared to controls. ${ }^{*} P<0.05$. No. of samples: 8. 
TABLE 2

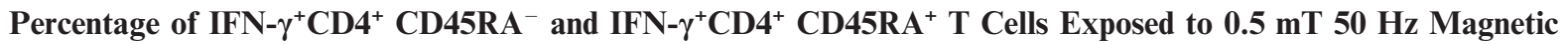
Fields and Static Magnetic Fields and Sham-Exposed Cells after $24 \mathrm{~h}$ of Cell Culture

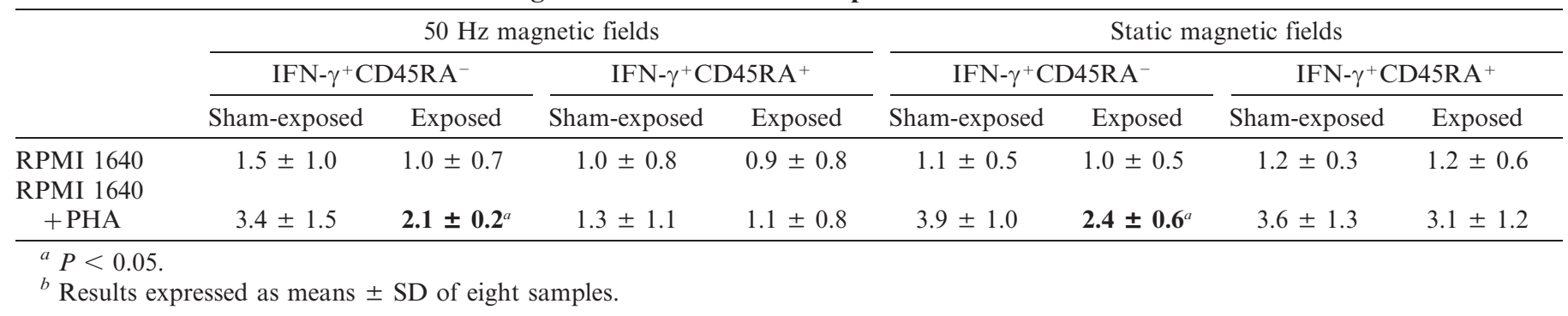

$\mathrm{CD}^{+} \mathrm{CD}^{+} 5 \mathrm{RA}^{-}$subset; the $\mathrm{CD} 4{ }^{+} \mathrm{CD}^{-} 5 \mathrm{RA}^{+}$subset produced only a small amount of IFN- $\gamma$. In exposed $\mathrm{CD}^{+} \mathrm{T}$ cells stimulated with PHA, the amount of IFN$\gamma$ in the supernatants decreased by $25 \%$ compared to sham-exposed cells. In $\mathrm{CD}^{+}{ }^{+} \mathrm{CD} 45 \mathrm{RA}^{-} \mathrm{T}$ cells stimulated with PHA, the amount of IFN- $\gamma$ in the supernatants decreased $21 \%$ in exposed cells compared to shamexposed cells; no significant difference in IFN- $\gamma$ release was observed in $\mathrm{CD}^{+}{ }^{+} \mathrm{CD} 45 \mathrm{RA}^{+} \mathrm{T}$ cells stimulated with PHA.

The results clearly indicate that the $\mathrm{CD} 4{ }^{+} \mathrm{CD} 45 \mathrm{RA}^{-}$ subset was more sensitive to the release of IFN- $\gamma$ upon subsequent exposure to $50 \mathrm{~Hz}$ magnetic fields.

To determine whether magnetic fields affect the PHA binding to the cell membrane, the cells were stimulated with PHA during and after exposure, washed to eliminate the unbound PHA, and incubated for $24 \mathrm{~h}$. Exposure to the magnetic fields and static magnetic fields did not modify the ability of PHA to stimulate cells as evaluated by IFN $-\gamma$ release.

Intracellular IFN- $\gamma$ in $\mathrm{CD}^{+} \mathrm{CD} 45 \mathrm{RA}^{+}$and $\mathrm{CD}^{+}$ CD45RA $A^{-}$T Cells Exposed to $0.5 \mathrm{mT} 50 \mathrm{~Hz}$ Magnetic Fields and Static Magnetic Fields after 24 h of In Vitro Culture

To determine whether the magnetic fields effect on IFN- $\gamma$ release was dependent on a minor production of this cytokine, the percentage of IFN- $\gamma$-positive cells in exposed and sham-exposed cells stimulated or not with PHA was evaluated by flow cytometry. The results are shown in Table 2.

After the $50 \mathrm{~Hz}$ magnetic-field exposure, a significant difference in the percentage of IFN $-\gamma+\mathrm{CD} 4^{+\mathrm{T}}$ cells was observed only in the exposed $\mathrm{CD} 4{ }^{+} \mathrm{CD} 4 \mathrm{RA}^{-}$subset stimulated with PHA (Table 2).

After $48 \mathrm{~h}$ of culture, the percentages of intracellular IFN- $\gamma+\mathrm{CD}^{+}{ }^{+} \mathrm{CD} 45 \mathrm{RA}^{-}$and $\mathrm{CD} 4{ }^{+} \mathrm{CD} 45 \mathrm{RA}^{+} \mathrm{T}$ cells in exposed or sham-exposed samples stimulated or not with PHA were not significantly different (data not shown).

The experiment was repeated, exposing the two T-cell subsets $\left(\mathrm{CD}^{+}{ }^{+} \mathrm{CD} 4 \mathrm{RA}^{-}\right.$and $\left.\mathrm{CD} 4{ }^{+} \mathrm{CD} 45 \mathrm{RA}^{+}\right)$to a 0.5
$\mathrm{mT}$ static magnetic field. A significant difference in IFN $-\gamma^{+}$cells was observed after $24 \mathrm{~h}$ of in vitro culture only in the $\mathrm{CD}^{+}{ }^{+} \mathrm{CD} 45 \mathrm{RA}^{-}$subset stimulated with PHA after $2 \mathrm{~h}$ of exposure to the static magnetic field (Table 2).

After $48 \mathrm{~h}$ of culture, the percentages of intracellular IFN $-\gamma^{+}$cells in both the $\mathrm{CD} 4{ }^{+} \mathrm{CD} 45 \mathrm{RA}^{-}$and $\mathrm{CD} 4{ }^{+} \mathrm{CD} 45 \mathrm{RA}^{+}$subsets remained constant compared to the percentages found in the same subsets of cells exposed to the static magnetic field in either the sample stimulated with PHA or the sample cultured in RPMI 1640 medium as the control (data not shown).

In conclusion, we observed that there was a significant difference in the percentage of IFN $-\gamma^{+} \mathrm{CD}^{+}{ }^{+} \mathrm{CD} 45 \mathrm{RA}^{-} \mathrm{T}$ cells at $24 \mathrm{~h}$ in exposed cells compared to sham-exposed cells stimulated with PHA. Additional experiments are required to explain the enhanced effect of PHA in exposed cells.

\section{Proliferation in $\mathrm{CD}^{+}$T-Cell Subsets}

Upon mitogenic stimulation after the exposure to the $0.5 \mathrm{mT} 50 \mathrm{~Hz}$ magnetic field and static magnetic field, the proliferation of $\mathrm{CD}^{+}{ }^{+} \mathrm{CD} 45 \mathrm{RA}^{-}$and $\mathrm{CD} 4{ }^{+} \mathrm{CD} 45 \mathrm{RA}^{+} \mathrm{T}$ cells was also investigated by FACS analysis using the antiKi67 antibody.

The Ki67 protein is accumulated from $G_{1}$ phase to mitosis, where it reaches the highest levels $(48 \mathrm{~h}$ after PHA stimulation). Cell proliferation was evaluated as the stimulation index and was expressed as the median percentage of cells expressing this protein.

The percentages of $\mathrm{Ki}^{+} 7^{+} \mathrm{CD}^{+}{ }^{+} \mathrm{CD}_{4} 4 \mathrm{RA}^{+}$and $\mathrm{CD}^{+} \mathrm{CD}^{+} 5 \mathrm{RA}^{-} \mathrm{T}$ cells in exposed samples and samples sham-exposed to the $50 \mathrm{~Hz}$ magnetic field or static magnetic field after $48 \mathrm{~h}$ of cell culture are shown in Table 3.

The results of the FACS analysis demonstrated that the stimulation index of exposed $\mathrm{Ki}^{6} 7^{+} \mathrm{CD} 4{ }^{+} \mathrm{CD} 45 \mathrm{RA}^{-}$ $\mathrm{T}$ cells compared to sham-exposed cells regardless of the magnetic field applied. No significant differences in proliferation were observed in $\mathrm{CD} 4{ }^{+} \mathrm{CD} 45 \mathrm{RA}^{+} \mathrm{T}$ cells stimulated with PHA after exposure to the $0.5 \mathrm{mT} 50 \mathrm{~Hz}$ ELF and static magnetic field (Table 3). 
TABLE 3

Stimulation Index of $\mathrm{Ki}^{+} \mathrm{CD4}^{+} \mathrm{CD}^{+} \mathrm{RA}{ }^{-}$and $\mathrm{Ki}^{+} 7^{+} \mathrm{CD4}^{+} \mathrm{CD}^{-} \mathrm{RA}^{+} \mathrm{T}$ Cells Exposed to $0.5 \mathrm{mT} 50 \mathrm{~Hz}^{\mathrm{Magnetic}}$ Fields or Static Magnetic Fields and Sham-Exposed Cells after $48 \mathrm{~h}$ of Cell Culture

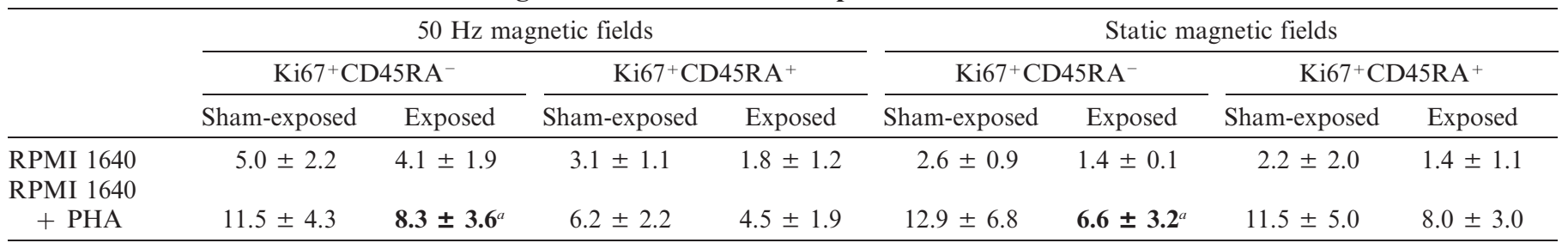

${ }^{a} P<0.05$.

${ }^{b}$ Data are expressed as means $\pm \mathrm{SD}$ of eight samples.

\section{Intracellular Calcein in $C D 4^{+} C D 45 R A^{-} T$ and $C D 4^{+}$ CD45RA $A^{+}$T Cells}

To understand the mechanisms contributing to the differences in the rates of proliferation, the content of intracellular free calcium was evaluated as a biological indicator of viability/activation of cells, using anticalcein antibody in $\mathrm{CD}^{+} \mathrm{CD} 45 \mathrm{RA}^{-}$and $\mathrm{CD}^{+}{ }^{+}$ $\mathrm{CD}^{2} \mathrm{RA}^{+} \mathrm{T}$ lymphocytes stimulated or not with PHA after $24 \mathrm{~h}$ of culture after exposure to magnetic fields. Eight samples were analyzed for each kind of magnetic field, and values are reported as the mean fluorescence intensity for each sample.

The free calcium concentrations after $24 \mathrm{~h}$ in subpopulations of $\mathrm{CD}^{+} \mathrm{T}$ cells exposed or sham-exposed to the $0.5 \mathrm{mT} 50 \mathrm{~Hz}$ magnetic field or static magnetic field are shown in Fig. 2. Exposure to the static magnetic field induced a significant decrease of cytosolic freecalcium in exposed $\mathrm{CD} 4{ }^{+} \mathrm{CD} 45 \mathrm{RA}^{-} \mathrm{T}$ cells compared to cells that were sham-exposed and stimulated with PHA (Fig. 2A). Similar results were obtained after exposure to $50 \mathrm{~Hz}$ magnetic fields; there was a slight decrease of cytosolic free calcium only in exposed CD $4{ }^{+} \mathrm{CD} 45 \mathrm{RA}^{-}$ T cells stimulated with PHA compared to sham-exposed cells (Fig. 2B). These results indicate that the rate of cytosolic free calcium was decreased only in $\mathrm{CD}^{+}{ }^{+} \mathrm{CD} 45 \mathrm{RA}^{-} \mathrm{T}$ cells exposed to magnetic fields.

\section{DISCUSSION}

In this study, we focused on the effects of $50 \mathrm{~Hz}$ magnetic fields and static magnetic fields $(0.5 \mathrm{mT})$ on the release/content of IFN- $\gamma$, on cell proliferation and on the modifications of intracellular calcium in subsets of human $\mathrm{CD}^{+} \mathrm{T}$ cells divided on the basis of surface marker expression and their functional properties.

In the last 30 years, there has been an increasing public concern about the possible harmful effects of magnetic fields generated by power lines and domestic appliances. The omnipresence of the $50 \mathrm{~Hz}$ magnetic fields from domestic electricity sources in modern society makes it important to investigate possible deleterious health effects from exposure. In our previous investigations (11), we found evidence that $50 \mathrm{~Hz}$ magnetic fields affected the expression of surface markers, the release/content of IFN- $\gamma$, cell proliferation and intracellular calcium in $\mathrm{CD}^{+} \mathrm{T}$ cells. The mechanism by which the magnetic fields affect the lymphocyte response has not been fully elucidated. However, the release/content of cytokines and the proliferative activity of lymphocyte can be affected by the magnetic fields at several levels of signal transduction $(15,20)$. Such processes involve activation of numerous enzymes associated with different signaling pathways (21) that may be affected by the magnetic
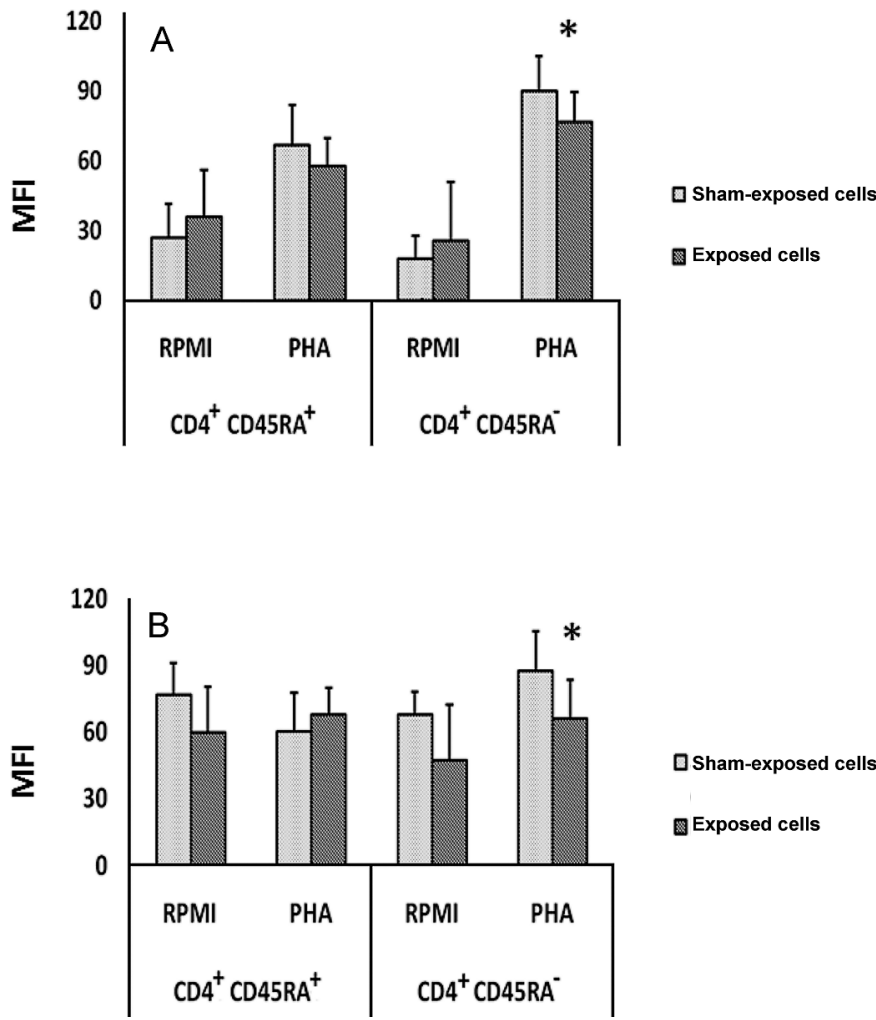

FIG. 2. Mean fluorescence intensity (MFI) of calcein in $\mathrm{CD}^{+}{ }^{+} \mathrm{CD} 45 \mathrm{RA}^{-}$and $\mathrm{CD}^{+}{ }^{+} \mathrm{CD} 45 \mathrm{RA}^{+}{ }^{+} \mathrm{T}$ cells exposed to static magnetic fields (panel A) or $50 \mathrm{~Hz}$ magnetic fields (panel B) and sham-exposed after $24 \mathrm{~h}$ of cell culture. Data are expressed as the mean fluorescence intensity of exposed cells compared to controls. ${ }^{*} P$ $<0.05$. No. of samples: 8 . 
fields. Bersani et al. (22) reported that magnetic fields induced the clustering of large intramembrane proteins, for example, receptors, enzymes and ion channels.

Static magnetic fields are time-independent fields of constant strength. As opposed to electrostatic fields, static magnetic fields are difficult to shield and can penetrate biological tissues freely. They interact directly with moving charges (ions, proteins, etc.) and magnetic materials found in tissue through several physical mechanisms (23). Static magnetic fields are one of the key components of magnetic resonance imaging (MRI), which has been introduced in many hospitals as a useful diagnostic tool because it does not cause any injury or fatigue.

We observed that $0.5 \mathrm{mT} 50 \mathrm{~Hz}$ magnetic fields or static magnetic fields induced a decrease in the release and content of IFN- $\gamma$ in $\mathrm{CD}^{+}{ }^{+} \mathrm{CD} 45 \mathrm{RA}^{-}$cell subsets. This alteration was more evident at $24 \mathrm{~h}$ for both magnetic fields. The release of IFN- $\gamma$ from exposed $\mathrm{CD} 4{ }^{+} \mathrm{CD} 45 \mathrm{RA}^{-} \mathrm{T}$ cells was significantly decreased compared to that released by $\mathrm{CD} 4{ }^{+} \mathrm{CD} 45 \mathrm{RA}^{-} \mathrm{T}$ cells that were sham-exposed and stimulated with PHA.

FACS analysis showed that the CD4 ${ }^{+} \mathrm{CD} 45 \mathrm{RA}^{-} \mathrm{T}-$ cell population is the most sensitive to the magnetic fields $(50 \mathrm{~Hz}$ or static magnetic fields). The content of IFN- $\gamma$ was significantly decreased in this subset after $24 \mathrm{~h}$ of exposure to the magnetic fields. However, this decrease was reversed after $48 \mathrm{~h}$ of cell culture, when the difference in the percentage of IFN- $\gamma^{+}$cells in exposed and sham-exposed cells was not significant.

We also observed a decrease in cell proliferation from exposure to both magnetic fields in the $\mathrm{CD} 4{ }^{+} \mathrm{CD} 45 \mathrm{RA}^{-}$ subset after $48 \mathrm{~h}$. Several approaches have been developed to study cell proliferation, including the labeling index, measurement of the S-phase fraction, the cytosolic TK assay, and the Ki-67 marker. In our study, cell proliferation was evaluated using an anti-Ki67 monoclonal antibody (24). The Ki-67 molecule is the most widely used marker for proliferation in clinical practice; it is expressed in all active phases of the cell cycle and is absent in quiescent cells. The analysis of intracellular calcium showed that the $\mathrm{CD}^{+}{ }^{+} \mathrm{CD} 45 \mathrm{RA}^{-}$ T-cell subset was more sensitive to the magnetic fields after $24 \mathrm{~h}$ of cell culture. In this cell subset, the free calcium concentration was higher in sham-exposed cells than in exposed cells.

The calcium ion is an important intracellular signal that is involved in many cellular pathways. It is associated with lymphocyte activation $(10,25)$, and many studies have reported the biological effects of static or pulsed magnetic fields on membrane ion transport. The influence of magnetic fields on the movement of calcium ion in the context of membranes could explain the diversity and variety of cellular responses observed in cell proliferation, cell differentiation and release of cytokines.
The results reported here, show that the subset most sensitive to the effects of the $50 \mathrm{~Hz}$ magnetic fields and static magnetic fields is $\mathrm{CD}^{+}{ }^{+} \mathrm{CD} 45 \mathrm{RA}^{-}$and that magnetic fields have a significant influence on cells stimulated with PHA.

We found that $0.5 \mathrm{mT}$ magnetic fields produced a significant effect only in activated cells, probably because the PHA stimulus amplifies the influence of magnetic fields on $\mathrm{CD}^{+}{ }^{+} \mathrm{CD} 45 \mathrm{RA}^{-} \mathrm{T}$ cells. However, the effect of magnetic fields is transient and is completely reversed after $48 \mathrm{~h}$ in the case of the $50 \mathrm{~Hz}$ magnetic fields and static magnetic fields.

We do not believe that the magnetic fields affect any particular pathway but rather that they influence all cell activities and that these effects are amplified in cells stimulated with PHA. This peculiarity could suggest the use of magnetic fields to support the traditional therapies for chronic degenerative pathologies in which subsets of the immune system are involved. We hypothesize that the use of magnetic fields for modulation of the role of $\mathrm{CD} 4^{+} \mathrm{T}$ cells and cytokine release in immune response could be used to develop new therapeutic strategies in medicine.

Our results do not explain why both magnetic fields influence only one subset of the CD4 ${ }^{+} \mathrm{T}$-cell population; only the $\mathrm{CD}^{+} \mathrm{CD}^{+} 5 \mathrm{RA}^{-}$subpopulation appears to produce the bulk of IFN- $\gamma$ after PHA stimulation (Fig. 1). This interpretation is not fully supported by data on the number of IFN- $\gamma^{+}$cells in the two subpopulations. The results suggest that $50 \mathrm{~Hz}$ magnetic fields and static magnetic fields delay IFN- $\gamma$ release by the $\mathrm{CD}^{+} \mathrm{CD}^{+} 5 \mathrm{RA}^{-}$subpopulation, which appears to be more sensitive to the magnetic fields effects in terms of cell proliferation rate. The reduced number of IFN- $\gamma$ positive cells in the CD45RA $\mathrm{R}^{-}$subpopulation supports this hypothesis. Further studies are required to determine the influence of different kinds of magnetic fields or electromagnetic fields like very high-frequency (VHF) magnetic fields on the immune system and to evaluate the biological effects of electric fields in combination with magnetic fields.

\section{ACKNOWLEDGMENTS}

This work has been supported by grants from the University of Palermo (60\% to AS). We would like to thank Prof. Maria Brai, DiFTeR - University of Palermo, for helpful comments. We would like to thank Dr. Catherine Paige for her help with editing.

Received: March 2, 2009; accepted: May 26, 2009

\section{REFERENCES}

1. IARC, Non-Ionizing Radiation, Part 1: Static and Extremely Low-Frequency (ELF) Electric and Magnetic Fields. IARC Monographs on the Evaluation of Carcinogenic Risks to Humans, Vol. 80, IARC, Lyon, 2002. 
2. Possible Health Effects from Terrestrial Trunked Radio (TETRA): Report of an Advisory Group on Non-ionising Radiation. Documents of the NRPB, Vol. 12, No. 2, NRPB, Chilton, UK, 2001.

3. A. Cossarizza, D. Monti, F. Bersani, R. Paganelli, G. Montagnani, R. Cadessi, M. Cantini and C. Franceschi, Extremely low frequency pulsed electromagnetic fields increase interleukin-2 (IL-2) utilization and IL-2 receptor expression in mitogen-stimulated human lymphocytes from old subjects. FEBS Lett. 248, 141-144 (1989).

4. B. Yokus, M. Z. Akdag, S. Dasdag, D. U. Cakir and M. Kizil, Extremely low frequency magnetic fields cause oxidative DNA damage in rats. Int. J. Radiat. Biol. 84, 789-795 (2008).

5. Y. Wei, H. Xiaolin and S. Tao, Effects of extremely lowfrequency-pulsed electromagnetic field on different-derived osteoblast-like cells. Electromagn. Biol. Med. 27, 298-311 (2008).

6. M. T. Santini, A. Ferrante, G. Rainaldi, P. Indovina and P. L. Indovina, Extremely low frequency (ELF) magnetic fields and apoptosis: a review. Int. J. Radiat. Biol. 81, 1-11 (2005).

7. International Commission on Non-Ionizing Radiation Protection, Guidelines on limits of exposure to static magnetic fields. Health Phys. 66, 100-106 (1994).

8. International Non-ionizing Radiation Committee of the International Radiation Protection Association, Interim guidelines on limits on exposure to $5060 \mathrm{~Hz}$ electric and magnetic fields. Health Phys. 58, 113122 (1990).

9. C. Aldinucci, J. Garcia Blanco, M. Palmi, G. Sgaragli, A. Benocci, A. Meini, F. Pessina, C. Rossi, C. Bonechi and G. P. Pessina, The effect of exposure to high flux density static and pulsed magnetic fields on lymphocyte function. Bioelectromagnetics 24, 373-379 (2003).

10. E. M. Goodman, B. Greenebaum and M. T. Marron, Effects of electromagnetic fields on molecules and cells. Int. Rev. Cytol. 158, 279-338 (1995).

11. S. Salerno, C. La Mendola, A. Lo Casto, G. Mamone, N. Caccamo, A. E. Cardinale and A. Salerno, Reversible effect of MR and ELF magnetic fields $(0.5 \mathrm{~T}$ and $0.5 \mathrm{mT})$ on human lymphocyte activation patterns. Int. J. Radiat. Biol. 82, 77-85 (2006).

12. M. Simkó and M. O. Mattsson, Extremely low frequency electromagnetic fields as effectors of cellular responses in vitro: possible immune cell activation. J. Cell Biochem. 93, 83-92 (2004).

13. C. A. Morehouse and R. D. Owen, Exposure of Daudi cells to low-frequency magnetic fields does not elevate MYC steady-state mRNA levels. Radiat. Res. 153, 663-669 (2000).
14. K. R. Foster, Mechanisms of interaction of extremely low frequency electric fields and biological systems. Radiat. Prot. Dosimetry 106, 301-310 (2003).

15. C. Aldinucci, J. Garcia Blanco, M. Palmi, G. Sgaragli, A. Benocci, A. Meini, F. Pessina, C. Rossi, C. Bonechi and G. P. Pessina, The effect of strong static magnetic fields on lymphocytes. Bioelectromagnetics 24, 109-117 (2003).

16. M. Ruggiero, D. P. Bottaro, G. Liguri, M. Gulisano, B. Peruzzi and S. Pacini, $0.2 \mathrm{~T}$ magnetic field inhibits angiogenesis in chick embryo chorioallantoic membrane. Bioelectromagnetics 25, 390396 (2004)

17. H. Okano, Effects of static magnetic fields in biology: role of free radicals. Front. Biosci. 13, 6106-6125 (2004).

18. H. Okano, N. Tomita and Y. Ikada, Effects of $120 \mathrm{mT}$ static magnetic field on TGF-betal-inhibited endothelial tubular formation in vitro. Bioelectromagnetics 28, 497-499 (2007).

19. X. Saulquin, C. Ibisch, M. A. Peyrat, E. Scotet, M. Hourmant, H. Vie, M. Bonneville and E. Houssaint, A global appraisal of immunodominant $\mathrm{CD}^{+} \mathrm{T}$ cell responses to Epstein-Barr virus and cytomegalovirus by bulk screening. Eur. J. Immunol. 30, 2531-2539 (2000).

20. P. Boscolo, A. Bergamaschi, M. B. Di Sciascio, F. Benvenuti, M. Reale, F. Di Stefano, P. Conti and M. Di Gioacchino, Effects of low frequency electromagnetic fields on expression of lymphocyte subsets and production of cytokines of men and women employed in a museum. Sci. Total Environ. 270, 13-20 (2001).

21. R. B. Frankel and R. P. Liburdy, Biological effects of static magnetic fields. In Handbook of Biological Effects of Electromagnetic Fields, 2nd ed. (C. Polk and E. Postow, Eds.), pp. 149-183. CRC Press, Boca Raton, FL, 1996.

22. F. Bersani, F. Marinelli, A. Ognibene, A. Matteucci, S. Cecchi, S. Santi, S. Squarzoni and N. M. Maraldi, Intramembrane protein distribution in cell cultures is affected by $50 \mathrm{~Hz}$ pulsed magnetic fields. Bioelectromagnetics 18, 463-469 (1997).

23. Magnetic Fields Health and Safety Guide. Health and Safety Guide No. 27, WHO, Geneva, 1989

24. A. Roman, T. Zyss and I. Nalepa, Magnetic field inhibits isolated lymphocytes, proliferative response to mitogen stimulation. Bioelectromagnetics 26, 201-206 (2005).

25. J. J. L. Carson, F. S. Prato, D. J. Drost, L. D. Diesbourg and S. J. Dixon, Time varying magnetic fields increase cytosolic free $\mathrm{Ca}^{+2}$ in HL-40 cells. Am. J. Physiol. 259, C687-C692 (1990). 